\title{
Acute and chronic effects of acidic pH on four subtropical frog species
}

\author{
Charon Farquharson ${ }^{1 *}$, Victor Wepener ${ }^{2}$ and Nico J Smit ${ }^{2}$ \\ ${ }^{\prime}$ Centre for Aquatic Research, University of Johannesburg, PO Box 524, Auckland Park,2006, South Africa \\ ${ }^{2}$ Unit for Environmental Sciences and Management, School of Biological Sciences, North West University, Private Bag X6001, Potchefstroom, 2520, \\ South Africa
}

\begin{abstract}
Acidic precipitation is implicated as a possible cause of global amphibian decline. Even protected areas such as Kruger National Park receive acid rain which may lead to possible negative effects on the park's natural amphibian populations. We conducted acute $\left(\mathrm{LC}_{50}\right)$ and chronic acid tolerance bioassays on embryos and tadpoles of four frog species found in the park, i.e., Chiromantis xerampelina (Southern Foam Nest Frog), Pyxicephalus edulis (African Bullfrog), Amietophrynus maculatus (Flat-backed Toad) and Hildebrandtia ornata (Ornate Frog), using survival, deformities and growth as endpoints. Chronic exposure $\mathrm{pH}$-values were selected based on the results of the acute assays. Trimmed Spearman-Karber $\mathrm{LC}_{50} \mathrm{~s}$ were $4.07,4.55$, 3.75 and 3.747 for C. xerampelina, P. edulis, A. maculatus and H. ornata, respectively, and were all below the $\mathrm{pHs}$ in the natural ponds of the KNP. For chronic exposures tadpole size decreased and tadpole deformities increased with decreasing $\mathrm{pH}$. Metamorphosis of tadpoles was also delayed by increasing acidity. In conclusion, the current buffering capacity of water bodies, which serve as habitat for amphibians, negates the effects of decreasing $\mathrm{pH}$ from acid precipitation.
\end{abstract}

Keywords: low $\mathrm{pH}$, acid precipitation, amphibians, mortality, developmental deformities, delayed metamorphosis, Kruger National Park.

\section{INTRODUCTION}

Various natural and anthropogenic emissions can influence the chemical composition of trace elements in the atmosphere (Mphepya et al., 2004). South Africa is a source of industrial pollution that is significant at a global scale (Josipovic et al., 2010) and atmospheric reactive nitrogen concentrations on the South African Highveld have also become a growing concern (Collett et al., 2010). The chemical composition of precipitation from the Amersfoort and Louis Trichardt areas has also been analysed (Mphephya et al., 2004), and $\mathrm{SO}_{4}^{2-}$ was the most abundant ion present. A large portion of this precipitation was also found to be acidic. On the South African Highveld, which stretches across parts of Gauteng, the Free State and Mpumalanga, approximately $30 \%$ of the land area is utilised for agricultural, urban and industrial activities (Collett et al., 2010). This region accounts for almost $75 \%$ of South Africa's industrial activity and is in effect responsible for about $90 \%$ of the nitrogen oxide $\left(\mathrm{NO}_{\mathrm{x}}\right)$ that is emitted in South Africa (Frieman and Piketh, 2003 in Collett et al., 2010). These authors also state that for the whole industrial Highveld area less than $15 \%$ of the total emitted nitrogen from power generation is deposited to the surface via wet and dry deposition; the rest remains in the atmosphere from where it gets transported out of the region. Various studies also show that the ions responsible for acidic precipitation are more abundant at certain times of the year, which coincide with the time of highest agricultural biomass combustion (Mphephya et al., 2004).

Mphepya et al. (2006) studied the chemical composition and sources that contribute to rainwater chemistry in the Skukuza area of the Kruger National Park (KNP), and found that rainwater from this area was acidic (average $\mathrm{pH}=4.72$ ). This acidity

\footnotetext{
* To whom all correspondence should be addressed.

๘ +27 721342816; e-mail: cfarkie@gmail.com

Received: 26 March 2015; accepted in revised form 4 November 2015
}

resulted from a mixture of mineral acids; consisting mainly of $\mathrm{H}_{2} \mathrm{SO}_{4}$ due to emissions of sulphur dioxide from the industrial region on the Highveld of South Africa (approximately 200-300 $\mathrm{km}$ from the KNP), as well as organic acids. As one of Africa's premier conservation areas, KNP has a mandate to conserve and manage all indigenous wildlife and vegetation occurring in their region. Amphibians are an important component of South Africa's exceptional biodiversity. According to Vlok et al. (2013), 117 species of frog are known in South Africa, and a combination of both historic and recent field surveys has resulted in 34 frog species being recorded from the Kruger National Park. Many of the KNP frog species breed in small ponds or pools, which could potentially be influenced by acidic rainfall.

Global amphibian population declines, range reduction and species extinctions have been reported with more regularity since the early 1980s and contribute to the world's current biodiversity crisis (Blaustein et al. 1994a, 1994b; Selvi et al., 2003; Whiles et al., 2006; Whitfield et al., 2007). Alarmingly, some species extinctions have even occurred in protected areas (Collins and Storfer, 2003). There has also been an increase in reported developmental malformations, especially limb deformities, occurring in amphibians (Hopkins et al., 2000; Kiesecker, 2002; Collins and Storfer, 2003; Johnson and Lunde, 2005). The normal rate of abnormalities (5\%) that occur naturally has in some cases increased to 15\% (Johnson and Lunde, 2005). Amphibians have moist, permeable skins and shell-less eggs which are directly exposed to the soil, water and sunlight, and can absorb toxic substances present in their surrounding environment (Blaustein et al., 1994, 2003; Blaustein and Johnson, 2003; Huang et al., 2003). Their complex life cycles also expose them to both terrestrial and aquatic environmental hazards (Blaustein and Johnson, 2003; Omonona and Ekpenko, 2011). Since many species do not venture far from where they hatched, they also function as monitors of local conditions (Blaustein and Johnson, 2003). Most of the water bodies that serve as amphibian habitats or breeding localities (Pough, 1976; Pough and Wilson, 1977) dry up completely 
during the summer, which means the water has to be replaced annually with fresh precipitation (Pierce, 1987). The water chemistry of many amphibian habitats may be influenced strongly by acid precipitation (Pierce, 1987). Amphibians are especially sensitive to changes in precipitation, temperature and ultraviolet radiation (anthropogenic and natural stress) (Blaustein et al., 1994; Horne and Dunson, 1995; Blaustein and Johnson, 2003). Consequently, amphibians are considered to be excellent biological indicators of general environmental health (Blaustein et al., 1994; Horne and Dunson, 1995; Huang et al., 2003) and early warning systems to environmental degradation.

According to a 2000 review of citations regarding amphibians, most focused on effects of metals (23\%), acid precipitation (22\%) and nonchlorinated pesticides (19\%) (Sparling et al., 2010). Literature regarding amphibians has thus far been underrepresented when considering their ecological importance; however, since 2000, there has been a dramatic increase in the number of research studies and papers that focus on the effects of contaminants on amphibians, but a marked decrease in publications on acid precipitation (Sparling et al., 2010). Little is known about the specific effects of anthropogenic acid sources on amphibian communities (Blaustein et al., 2003; Bradford et al., 1992; Pierce, 1985). Several studies have focused on the effects of low or decreasing $\mathrm{pH}$ on frog tadpoles or embryos, but these are mainly related to the modifying effects that $\mathrm{pH}$ has on toxicants such as metals (Bradford et al., 1992; Vertucci and Corn, 1996; Räsänen et al., 2003; Ezemonye and Enuneku, 2005) and not solely to the effect of decreasing $\mathrm{pH}$. Although amphibians are currently considered more commonly in toxicity assessments, much work still remains if this group is going to be sufficiently represented in the discipline of ecotoxicology (Sparling et al., 2010). Our goal was to determine the acute acidity effect $\left(\mathrm{LC}_{50}\right.$ - lethal concentration resulting in $50 \%$ mortality) on tadpoles of 4 common frog species from the KNP. The influences of decreased $\mathrm{pH}$ on the growth of the four species were also determined following a chronic exposure period (4 weeks + ), by comparing the size of tadpoles exposed to different $\mathrm{pHs}$ and control solutions. To promote realism, we opted to conduct our experiments in the natural environment.

\section{MATERIALS AND METHODS}

\section{Ethical clearance}

The ethical considerations for the project (species selected, number of individuals, bioassay protocols, sacrificing of organisms) were approved by the University of Johannesburg Senate Ethics Committee. The handling of organisms was carried out according to the South African National Standard for the care and use of animals for scientific purposes (SANS 10386). Toxicity bioassays were conducted according to the standardised protocols developed for South African waters by the Department of Water Affairs (Slabbert et al. 1998).

\section{Test species}

We selected 4 frog species (Fig. 1) that occur within KNP: the Flat-backed Toad (Amietophrynus maculatus Hallowell, 1854),

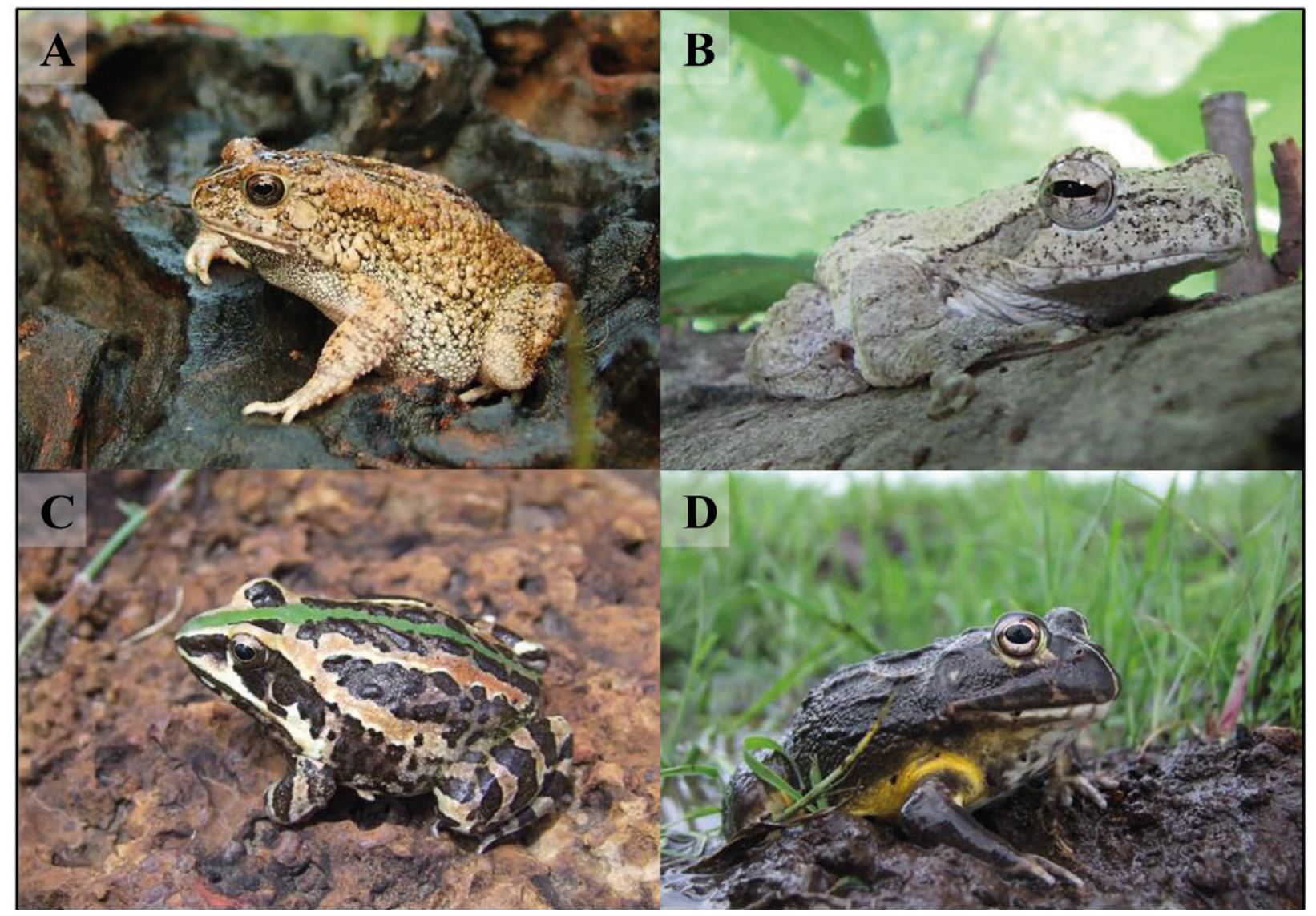

Figure 1

The four frog species that were collected and used during this study. A) Flat-backed Toad (Amietophrynus maculatus), B) Southern Foam Nest Frog (Chiromantis xerampelina), C) Ornate Frog (Hildebrandtia ornate) and D) African Bullfrog (Pyxicephalus edulis). (Photographs: C Farquharson) 
the Southern Foam Nest Frog (Chiromantis xerampelina Peters, 1854), Ornate Frog (Hildebrandtia ornata Peters, 1878) and African Bullfrog (Pyxicephalus edulis Peters, 1854). Southern Foam Nest Frogs are an arboreal species occurring around seasonal or permanent bodies of open water in a variety of bushveld vegetation types in the savannah biome (Du Preez and Carruthers, 2009). Eggs are deposited into foam nests that are suspended, usually in trees or branches if available, over water, while the tadpoles develop inside. The outer crust of the nests hardens, thus insulating tadpoles from temperature extremes and desiccation. This is the only species of Chiromantis that occurs in southern Africa. The African Bullfrog occurs in shallow temporary ponds and marshy areas in open savannah woodland in eastern and southern Africa (Du Preez and Carruthers, 2009). African Bullfrogs only require seasonal shallow, rain-filled depressions, but which retain water long enough for the tadpoles to metamorphose. These types of pools offer several advantages: water is warmed by the sun and thus stimulates rapid development of tadpoles, and fewer aquatic predators are present (Du Preez and Carruthers, 2009). During tadpole metamorphosis territorial males will show deliberate parental care by remaining with the tadpoles in the pools. Adult frogs are also fossorial and remain buried for most of the year, only emerging during the breeding season. This species is one of two Bullfrog species occurring in southern Africa. The Ornate Frog is a burrowing species which occurs in a variety of savannah types of vegetation. They hibernate in deep, sandy soils and only surface during the breeding season, where they use shallow water at the edge of tropical bushveld ponds ( $\mathrm{Du}$ Preez and Carruthers, 2009). This species is the only species of Ornate Frog that occurs in southern Africa. The Flat-backed Toad prefers shallow, static or slow-moving water in rivers, weirs and dams in a variety of vegetation types in grassland and savannah (Du Preez and Carruthers, 2009).

\section{Sampling}

We sampled during the late spring and summer months (November, December, and January) of 2010-2012 at 5 sites in the southern regions of the KNP, South Africa (Fig. 2). All five sites fall within the acid rain deposition area in the KNP (Mphepya et al., 2006). Newly-laid foam nests were collected for C. xerampelina, while eggs or newly-hatched tadpoles were collected from the sampling sites for the other three frog species. Acute and chronic acid tolerance bioassays were carried out on tadpoles (stages 20-25 according to Gosner, 1960) of the four frog species, while acute bioassays were conducted on the embryos of the same four species. Acute $\mathrm{LC}_{50}$-type tests were conducted and concluded while in the field, whereas chronic exposures were initiated (i.e., hatching of tadpoles up to 3 weeks of age) in the field laboratory and then transported in exposure medium to the laboratories at the University of Johannesburg where the exposures were terminated upon metamorphosis to the juvenile frog stage.

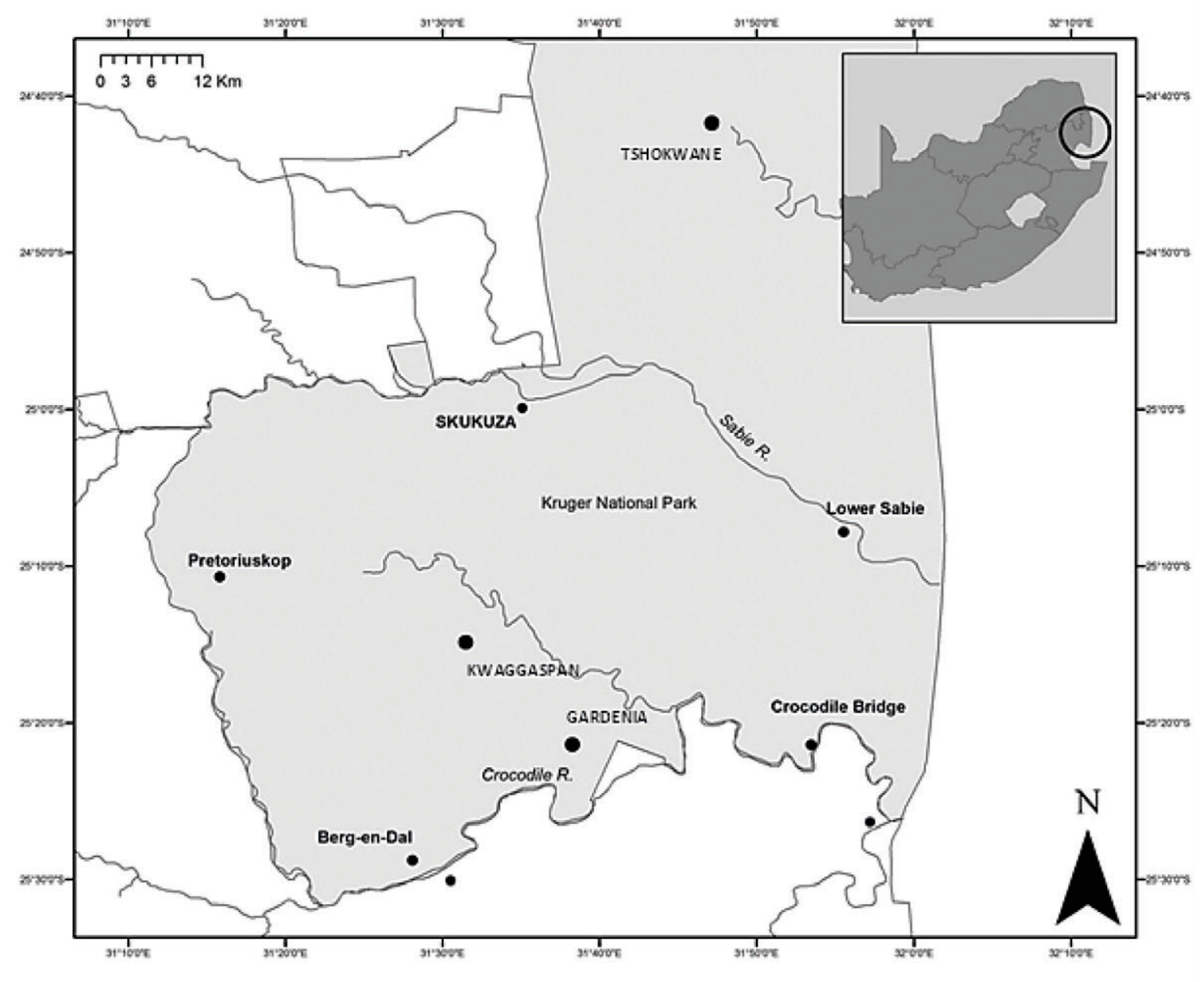

Figure 2

A map showing the southern region of the Kruger National Park, South Africa, where most of the frog collection sites were situated. 


\section{Acute acid tolerance bioassays}

For this assay, $\mathrm{LC}_{50}$-type tests using hatching success and mortality were performed on eggs and tadpoles, respectively, of the four test species, using solutions with decreasing $\mathrm{pH}$-values to ascertain at which $\mathrm{pH}$-value $50 \%$ of exposed individuals would be affected. The $\mathrm{pH}$-solutions were achieved by adding varying volumes of ultra-pure $98 \%$ sulphuric acid to de-chlorinated tap water. Eight different pH-values $(6.85,6,5.5,5,4.5,4,3.5$ and $\mathrm{pH}=3$ solutions) were used for three of the frog species during this acute bioassay with de-chlorinated tap water as the exposure medium. In addition a positive control $\left(1 \mathrm{mg} / \mathrm{L} \mathrm{CdCl}_{2}\right.$ in tap water) as well as negative control (pond water $(\mathrm{pH}= \pm 7)$ ) were conducted concurrently. For $P$. edulis eggs and tadpoles the lowest $\mathrm{pH}$ exposure was at $\mathrm{pH}=4$. According to the standard protocol for acute toxicity assays, exposures for each of the frog species were conducted in triplicate, in 10-L clear, polypropylene containers. However, for H. ornata, exposures were only duplicated, due to the restricted number of tadpoles that could be collected. All exposures were conducted in a field laboratory in the same region where the tadpoles were collected, to replicate prevailing environmental conditions that would be experienced in the field as much as possible. Exposure containers were randomly placed within a demarcated area, and set under shade cloth to minimize effects of temperature and water evaporation. This ensured that the daylight hours and temperature variations still remained somewhat similar to the field conditions. To keep the density as low as possible, 20-25 tadpoles of each frog species were placed in each container ( $2-3$ tadpoles/L), thus avoiding possible density-dependent effects. Tadpoles were kept in these containers for a period of $96 \mathrm{~h}$. Every $24 \mathrm{~h}$ the $\mathrm{pH}$ was checked with a WTW Instruments $\mathrm{pH}$ probe and rectified to the required $\mathrm{pH}$ of the exposure medium if necessary. Tadpoles were fed daily with small amounts of ground commercial fish flakes and lettuce leaves. Excess food was siphoned out of the containers to reduce any confounding influences. Mortalities were noted every $24 \mathrm{~h}$ and dead individuals removed from the containers.

Ten embryos for three of the species (C. xerampelina, $P$. edulis and A. maculatus) were also placed in smaller containers containing the same $\mathrm{pH}$-solutions in order to determine the effects that decreasing $\mathrm{pH}$ would have on the natural development of the eggs and the hatching process. For the purposes of this study, C. xerampelina embryos were removed from the foam nests to test the effects of decreasing $\mathrm{pH}$. Normally eggs would be protected in the foam nests until tadpoles developed and emerged from the nests. These bioassays were also conducted in triplicate. Exposures could not be performed on $H$. ornata since no embryos were sampled, only tadpoles.

Mortality data for each of the four frog species were recorded every $24 \mathrm{~h}$ for a period of $96 \mathrm{~h}$ and tabulated. Prior to calculating $\mathrm{LC}_{50}$ values, the exposure $\mathrm{pHs}$ were converted to $-\log \left[\mathrm{H}^{+}\right]$to obtain an increasing dose-response relationship, as is required for toxicity testing. The data from the natural pond water were not included in the calculation of the $\mathrm{LC}_{50}$ (even though for three of the four species mortalities were below the permissible 10\%), due to the possible influence of natural organic material and other substances on the survival of the tadpoles during the exposure period. Where applicable the Trimmed Spearman-Karber (freeware obtained from the Environmental Protection Agency) or the Probit models were applied to calculate the individual $\mathrm{LC}_{50}$ $\mathrm{pH}$-values and confidence limits of the four frog species. The significance of the differences in $\mathrm{LC}_{50}$ values recorded between the species was tested using the comparison of fudicial limits as proposed by Sprangue and Vogels (1977).

\section{Chronic acid tolerance bioassays}

We selected chronic exposure $\mathrm{pH}$ values based on the outcome of the acute bioassays and used 30-L polypropylene containers (Fig.3A and B). Exposure conditions were similar to those described for the acute bioassays. For C. xerampelina, A. maculatus and $H$. ornata, $7 \mathrm{pH}$-solutions were used (pond water, de-chlorinated tap water, $\mathrm{pH}=6 ; 5.5 ; 5 ; 4.5$ and 4 ), and for $P$. edulis, only 6 solutions were used (pond water, de-chlorinated tap water, $\mathrm{pH}=6 ; 5.5 ; 5$ and 4.8 ). Each container contained 30 tadpoles (density - 1 tadpole/L), except for H. ornata, which only contained 10 tadpoles in each 10-L container (density - 1 tadpole/L), due to restriction of sampled individuals. To determine the effect on growth, tadpoles (Gosner stages 20-25) were measured at the onset of the bioassay, weighed and measured again after a period of 3 weeks, and at the termination of each exposure. For the purposes of this study the chronic exposures and $\mathrm{pH}$ adjustments were ceased when tadpoles (Gosner stage 36-41) developed hind limbs (Fig. 3E - J). During the exposures, temperature was measured and $\mathrm{pH}$-levels were maintained at the required exposure $\mathrm{pH}$ (Fig. 3C). Water was changed once a week and $\mathrm{pH}$ was once again adjusted every $24 \mathrm{~h}$ to the specific exposure $\mathrm{pH}$. Tadpoles were fed with small amounts of ground fish flakes and lettuce leaves. As with the standardised acute bioassays exposures were conducted in triplicate for three of the frog species and in duplicate for $H$. ornata. Time (24-h period) from the start of each exposure to the development of hind limbs was noted. This time frame was then compared to the known periods in which metamorphosis is completed for each of the frog species to see whether metamorphosis was influenced by acidic pHs. Mobility as well as any morphological defects in tadpoles were also noted, specifically changes to tadpole pigmentation and tail abnormalities. These were, however, not quantified and therefore are not used to quantify chronic effects.

The significance of the effect of decreasing $\mathrm{pH}$ on mean body length and weight of the tadpoles was assessed using one-way analysis of variance (ANOVA). Data were tested for homogeneity of variance using Levene's test prior to applying post-hoc comparisons. Post-hoc comparisons were made using the Scheffè test for homogenous or Dunnett's-T3 test for nonhomogenous data. The use of either one of the two tests resulted in the determination of significant differences $(p<0.05)$ between variables.

\section{RESULTS}

\section{Acute acid tolerance bioassays}

The positive control resulted in $100 \%$ mortality in all four species. Tadpoles had $100 \%$ mortality within $24 \mathrm{~h}$ of the start of the assays at $\mathrm{pH} 3.5$ and lower. The $\mathrm{LC}_{50} \mathrm{pH}$-values of the four frog species ranged from $\mathrm{pH} 4.55$ to as low as $\mathrm{pH} 3.74$ (Table 1). A. maculatus and H. ornata were the least sensitive species with low $\mathrm{LC}_{50} \mathrm{pH}$-values of $\mathrm{pH} 3.75$ and 3.74, respectively. Chiromantis xerampelina acidity tolerance was significantly lower than that of the other three species.

The embryos of C. xerampelina and P. edulis did not hatch at $\mathrm{pH}$ exposures below 4.5, whereas $A$. maculatus had no hatching below pH 4 (Table 2). However, C. xerampelina appeared to display a dependency on low $\mathrm{pHs}$ for hatching to take place, since the natural pond water and near-neutral control resulted in no and low (33.3\%) hatching success. The hatching success increased with a decrease in $\mathrm{pH}$ up to a threshold of $\mathrm{pH} 4.5$, 


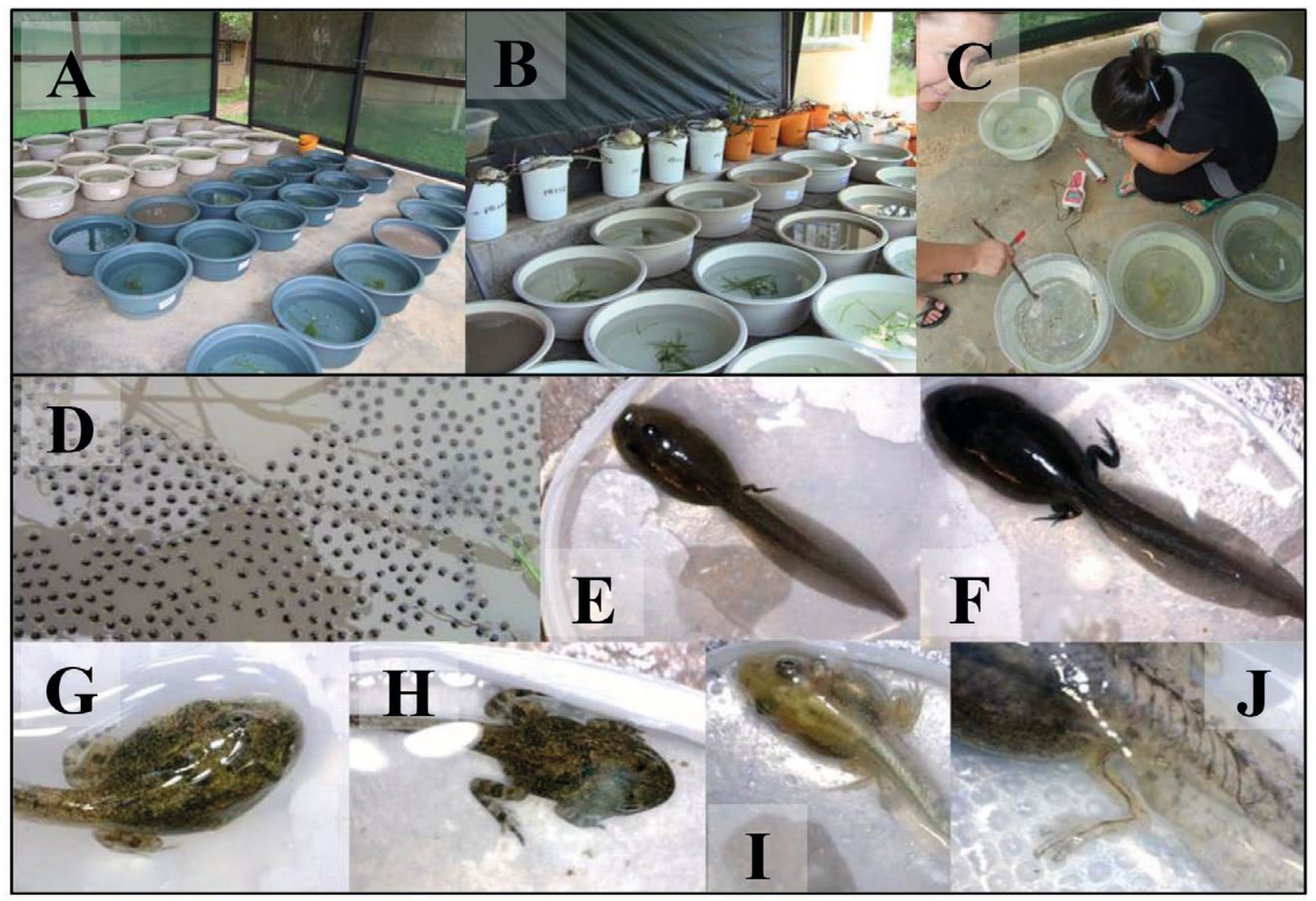

Figure 3

$A$ and B: 30-L containers used for chronic exposures. Each container marked and placed randomly in area shown in photograph. C: Adjusting of $p H$ every 24 h. D: Frog eggs floating on water surface. E and F: Development of hind legs in P. edulis tadpoles. G and H: A. maculatus tadpoles with hind legs. I: $\mathrm{H}$. ornata tadpole with hind legs. J: Hind leg of C. xerampelina tadpole.

after which there was no hatching. In contrast $A$. maculatus and $P$. edulis had virtually $100 \%$ hatching success in all the exposures (including the controls), up to the $\mathrm{pH} 4$ and 4.5 thresholds, respectively.

\section{Chronic acid tolerance bioassays}

Mortalities occurred in all four frog species during their long-term exposures. For the chronic bioassays the lowest $\mathrm{pH}$ exposure was selected to be above the $\mathrm{LC}_{50}$ value recorded in the acute tests. C. xerampelina had the highest mortality percentage (96\%) at $\mathrm{pH} 4$, whereas $\mathrm{H}$. ornata had the highest mortality percentage (90\%) at $\mathrm{pH}$ 5.5. A. maculatus had overall low percentages across the series of $\mathrm{pH}$ exposures, ranging from $2-7 \%$. P. edulis had high mortality percentages in both the $\mathrm{pH} 5$ and $\mathrm{pH} 4.8$ exposures.

All four species showed a general decrease in mean length (Fig. 4) and weight (Fig. 5) as the $\mathrm{pH}$ decreased. Thus tadpoles exposed to $\mathrm{pH} 4.5$ and lower were generally much smaller than tadpoles from the controls and higher $\mathrm{pH}$-groups.

Chiromantis xerampelina tadpoles (Fig. 4A) from the control (pond water) were significantly longer than tadpoles in the de-chlorinated tap water $(p=0.011), \mathrm{pH} 6(p=0.021)$ and pH4.5 $(p=0.001)$. Tadpoles exposed to $\mathrm{pH} 5.5$ and $\mathrm{pH} 5$ seemed to be less affected by the change in $\mathrm{pH}$. Their mean lengths were similar to that of the control in pond water. Tadpoles from the pH 4.5 and 4 exposures had the overall smallest mean length. There was no influence of $\mathrm{pH}$ on the mean lengths of $P$. edulis tadpoles (Fig. 4B). A decrease in mean length was recorded with the decrease in $\mathrm{pH}$ for A. maculatus tadpoles (Fig. 4C) with the exception of tadpoles exposed to $\mathrm{pH} 5.5$, which increased significantly in mean length when compared to the other exposure groups ( $p=0.03$ and 0.035 for tap water and 4 , respectively). For $H$. ornata (Fig. 4D), the tadpoles exposed to $\mathrm{pH} 5.5$ were also significantly longer than tadpoles in the other exposures $(p$ $=0.001 ; 0.0001 ; 0.0001 ; 0.0001 ; 0.0001$ and 0.001 for pond water, tap water, pH6, 5, 4.5 and 4 , respectively).

The weights of C. xerampelina tadpoles (Fig. 5A) in the $\mathrm{pH}$ $6,4.5$ and tap water exposure groups were all significantly lower than that of the tadpoles from the control pond water, with $p$ $=0.001 ; 0.00$ and 0.00 , respectively. The lowest weights were recorded for the lowest $\mathrm{pH}$ exposures and these results follow the same trend as those recorded for tadpole length. Tadpole weight from the $\mathrm{pH} 5$ exposure differed significantly from that for $\mathrm{pH} 6(p=0.046)$ and $\mathrm{pH} 4.5(p=0.026)$. There were no significant differences in mean weight for $P$. edulis tadpoles, following exposure to the different $\mathrm{pHs}$ (Fig. 5B). The exposure to different $\mathrm{pHs}$ did not influence the weight of $A$. maculatus tadpoles to a great extent (Fig. 5C), with only tadpoles in the $\mathrm{pH} 6$ exposure group decreasing significantly from the pond ( $p$ $=0.006)$ and tap water $(0.013)$ controls. The mean weight of $H$. ornata tadpoles in the $\mathrm{pH} 5.5$ exposure (Fig. 5D) was significantly greater than for any of the other exposures $(p=0.007$; $0.00 ; 0.00 ; 0.001 ; 0.001$ and 0.001 for pond water, tap water, $\mathrm{pH}$ $6,5,4.5$ and 4 , respectively).

All species' tadpoles from all of the different exposures 
TABLE 1

The " $\mathrm{LC}_{50}$ " pH-values with $95 \%$ confidence levels calculated for 4 frog species using the Trimmed Spearman-Karber and Probit methods where appropriate. Asterisks indicate data that were not included in the calculation of the $L_{50^{\circ}}$

\section{Frog species and $\mathrm{pH}$ exposures}

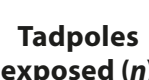
exposed $(n)$

Mortalities
(n)

(n)

“LC, " pH
value

Lower $95 \%$ confidence level

\section{C. xerampelina}

Positive control (cadmium chloride solution; $1 \mathrm{mg} / \mathrm{L}$ )

${ }^{*}$ Negative control (pond water; $\mathrm{pH} \pm 6.9$ )

De-chlorinated tap water $(\mathrm{pH} \pm 6.87)$

$\mathrm{pH} 6$

pH 5.5

$\mathrm{pH} 5$

$\mathrm{pH} 4$

pH 3.75

$\mathrm{pH} 3.5$

$\mathrm{pH} 3$

\begin{tabular}{|l|l|l|l|l|l|}
\hline 75 & 75 & & & \\
\hline 75 & 6 & & & \\
\hline 75 & 1 & $\mathrm{pH} 4.07$ & 3.996 & 4.149 \\
\hline 75 & 2 & & & \\
\hline 75 & 0 & & & \\
\hline 75 & 22 & & & \\
\hline 75 & 75 & & & \\
\hline 75 & 75 & & & \\
\hline 75 & 75 & & & \\
\hline 75 & & & & \\
\hline
\end{tabular}

P. edulis

Positive control (cadmium chloride solution; $1 \mathrm{mg} / \mathrm{L}$ )

*Negative control (pond water; $\mathrm{pH} \pm 6.9$ )

De-chlorinated tap water ( $\mathrm{pH} 6.87$ )

$\mathrm{pH} 6$

pH 5.5

pH 5

$\mathrm{pH} 4.5$

\begin{tabular}{|l|l|l|l|l|l|}
\hline 90 & 90 & & & \\
\hline 90 & 9 & & & \\
\hline 90 & 4 & $\mathrm{pH} 3.75$ & 3.742 & 3.762 \\
\hline 90 & 2 & & & \\
\hline 90 & 1 & & & \\
\hline 90 & 2 & & & \\
\hline
\end{tabular}

\section{A. maculatus}

Positive control (cadmium chloride solution; $1 \mathrm{mg} / \mathrm{L}$ )

${ }^{\star}$ Negative control (pond water; $\mathrm{pH} \pm 6.9$ )

De-chlorinated tap water ( $\mathrm{pH} 6.87$ )

$\mathrm{pH} 6$

pH 5.5

$\mathrm{pH} 5$

$\mathrm{pH} 4.5$

$\mathrm{pH} 4$

$\mathrm{pH} 3.5$

\begin{tabular}{|l|l|l|l|l|l|}
\hline 90 & 90 & & & \\
\hline 90 & 9 & & & \\
\hline 90 & 4 & & & \\
\hline 90 & 2 & $\mathrm{pH} 3.75$ & 3.742 & 3.762 \\
\hline 90 & 2 & & & \\
\hline 90 & 2 & & & \\
\hline 90 & 4 & & & & \\
\hline
\end{tabular}

H. ornata

Positive control (cadmium chloride solution; $1 \mathrm{mg} / \mathrm{L}$ )

${ }^{*}$ Negative control (pond water; $\mathrm{pH} \pm 6.9$ )

De-chlorinated tap water ( $\mathrm{pH} 6.87$ )

pH 6

$\mathrm{pH} 5.5$

$\mathrm{pH} 5$

$\mathrm{pH} 4.5$

$\mathrm{pH} 4$

$\mathrm{pH} 3.5$

\begin{tabular}{|l|l|l|l|l|l|}
\hline 20 & 20 & & & \\
\hline 20 & 3 & & & \\
\hline 20 & 0 & & $\mathrm{pH} \mathrm{3.74}$ & $\begin{array}{c}\text { no confidence } \\
\text { value }\end{array}$ & $\begin{array}{c}\text { no confidence } \\
\text { value }\end{array}$ \\
\hline 20 & 0 & & & \\
\hline 20 & 1 & & & \\
\hline 20 & 1 & & & \\
\hline 20 & 20 & & & \\
\hline
\end{tabular}




\begin{tabular}{|c|c|c|c|}
\hline \multicolumn{4}{|c|}{$\begin{array}{c}\text { TABLE } 2 \\
\text { Acute acid tolerance bioassay results of embryos, of } \\
\text { C. xerampelina, } P \text {. edulis and } A \text {. maculatus, exposed to } \\
\text { different pH concentrations. The number, as well as } \\
\text { percentage, of embryos that hatched and developed into } \\
\text { tadpoles is presented. }\end{array}$} \\
\hline $\begin{array}{l}\text { Frog species and } \\
\text { pH exposures }\end{array}$ & $\begin{array}{l}\text { Embryos } \\
\text { exposed }(n)\end{array}$ & \begin{tabular}{|c|} 
Embryos \\
hatched $(n)$
\end{tabular} & \begin{tabular}{|c|}
$\begin{array}{c}\text { Percentage } \\
\text { hatched }\end{array}$ \\
\end{tabular} \\
\hline \multicolumn{4}{|l|}{ C. xerampelina } \\
\hline $\begin{array}{l}\text { Negative control (pond } \\
\text { water; } \mathrm{pH} \pm 6.9 \text { ) }\end{array}$ & 30 & 0 & 0 \\
\hline $\begin{array}{l}\text { De-chlorinated tap } \\
\text { water }(\mathrm{pH} \pm 6.87)\end{array}$ & 30 & 10 & 33.3 \\
\hline pH 6 & 30 & 11 & 36.7 \\
\hline pH 5.5 & 30 & 16 & 53.3 \\
\hline pH 5 & 30 & 20 & 66.7 \\
\hline pH 4.5 & 30 & 27 & 90 \\
\hline $\mathrm{pH} 4$ & 30 & 0 & 0 \\
\hline pH 3.5 & 30 & 0 & 0 \\
\hline \multicolumn{4}{|l|}{ P.edulis } \\
\hline $\begin{array}{l}\text { Negative control (pond } \\
\text { water; } \mathrm{pH} \pm 6.9 \text { ) }\end{array}$ & 30 & 30 & 100 \\
\hline $\begin{array}{l}\text { De-chlorinated tap } \\
\text { water (pH 6.87) }\end{array}$ & 30 & 29 & 96.7 \\
\hline pH 6 & 30 & 28 & 93.3 \\
\hline pH 5.5 & 30 & 30 & 100 \\
\hline pH 5 & 30 & 29 & 96.7 \\
\hline pH 4.5 & 30 & 29 & 96.7 \\
\hline $\mathrm{pH} 4$ & 30 & 0 & 0 \\
\hline \multicolumn{4}{|l|}{ A. maculatus } \\
\hline $\begin{array}{l}\text { Negative control (pond } \\
\text { water; } \mathrm{pH} \pm 6.9 \text { ) }\end{array}$ & 30 & 28 & 93.3 \\
\hline $\begin{array}{l}\text { De-chlorinated tap } \\
\text { water (pH 6.87) }\end{array}$ & 30 & 28 & 93.3 \\
\hline pH 6 & 30 & 30 & 100 \\
\hline pH 5.5 & 30 & 28 & 93.3 \\
\hline pH 5 & 30 & 29 & 96.7 \\
\hline pH 4.5 & 30 & 28 & 93.3 \\
\hline $\mathrm{pH} 4$ & 30 & 27 & 90 \\
\hline pH 3.5 & 30 & 0 & 0 \\
\hline
\end{tabular}

started with their metamorphosis around the same time. In most of the species the control tadpoles (pond water and tap water) only started a day or two earlier than the rest of the exposures. For C. xerampelina the control exposures as well as the higher $\mathrm{pH}$ exposures ( $\mathrm{pH}$ 6, 5.5 and 5) had large numbers of tadpoles completing metamorphosis early on, while the lower $\mathrm{pH}$ exposures (pH 4.5 and 4) at first had a only a few individuals completing their metamorphosis with the bulk of the remaining tadpoles completing their metamorphosis at a later stage. For this frog species the control tadpoles completed metamorphosis first and the tadpoles from the low $\mathrm{pH}$ exposures finished last. For P. edulis tadpoles from the $\mathrm{pH} 6$ exposure completed metamorphosis first. Tadpoles from $\mathrm{pH} 5$ and 4.8 completed metamorphosis before tadpoles from tap water and $\mathrm{pH} 5.5$ exposures. For $A$. maculatus, tadpoles from pond control, tap water, pH 5.5 and 5 started metamorphosis before the other exposures and also finished before these exposures. The tadpoles from pH 4.5 and 4 were the last to complete their metamorphosis. This was also the case for the metamorphosis of $H$. ornata tadpoles.

The natural metamorphosis cycles for C.xerampelina and $H$. ornata tadpoles have not been documented previously, as has been done for both $A$. maculatus and P. edulis tadpoles. Tadpoles from the chronic exposure assays completed metamorphosis after 143 and 93 days for C. xerampelina and $H$. ornata, respectively (see Table 3). Tadpoles of P. edulis only started to develop hind legs after 25 days and all surviving tadpoles completed metamorphosis after 49 days (Table 3 ). Exposed A. maculatus tadpoles started to complete metamorphosis only after 36 days and all tadpoles completed metamorphosis after 84 days (Table 3).

\section{DISCUSSION}

According to Pierce (1987), amphibians are relatively acid tolerant; embryos of many species exhibit increased mortality only between $\mathrm{pH} 4$ and 4.5 and do not experience complete reproductive failure unless the $\mathrm{pH}$ is near or below 4 . All four frog species had $100 \%$ tadpole mortality at $\mathrm{pH} 3.5$ within $24 \mathrm{~h}$ and almost $50 \%$ mortality at $\mathrm{pH} 4-4.5$. Physical and behavioural abnormalities developed quickly in the lower $\mathrm{pH}$ conditions $\mathrm{pH}$ 4 and lower). These tadpoles became less vigorous; they did not feed as readily, which caused weight loss and decreased their growth rates. Some of the tadpoles also developed malformations such as crooked tails and all tadpoles exhibited a loss of pigmentation. These effects are similar to the results of previous studies (Grant and Licht, 1993; Kiesecker, 1996; Karraker, 2007). The behavioural and pigmentation differences were personal

\begin{tabular}{|c|c|c|c|c|}
\hline \multicolumn{5}{|c|}{$\begin{array}{c}\text { TABLE } 3 \\
\text { Comparison between the metamorphosis cycles of acid-exposed tadpoles and natural tadpoles, according to available } \\
\text { literature }\end{array}$} \\
\hline Frog species & $\begin{array}{l}\text { Duration of chronic } \\
\text { exposure assays }\end{array}$ & $\begin{array}{l}\text { first tadpoles } \\
\text { started to complete } \\
\text { metamorphosis }\end{array}$ & $\begin{array}{l}\text { Surviving tadpoles } \\
\text { to complete } \\
\text { metamorphosis }\end{array}$ & $\begin{array}{l}\text { Documented number of days } \\
\text { for tadpoles to complete } \\
\text { normal metamorphosis }\end{array}$ \\
\hline C. xerampelina & 39 & 54 & 143 & not documented \\
\hline P. edulis & 25 & 35 & 49 & 18-33 days \\
\hline A. maculatus & 27 & 36 & 84 & 14 days \\
\hline H. ornata & 31 & 43 & 93 & not documented \\
\hline
\end{tabular}




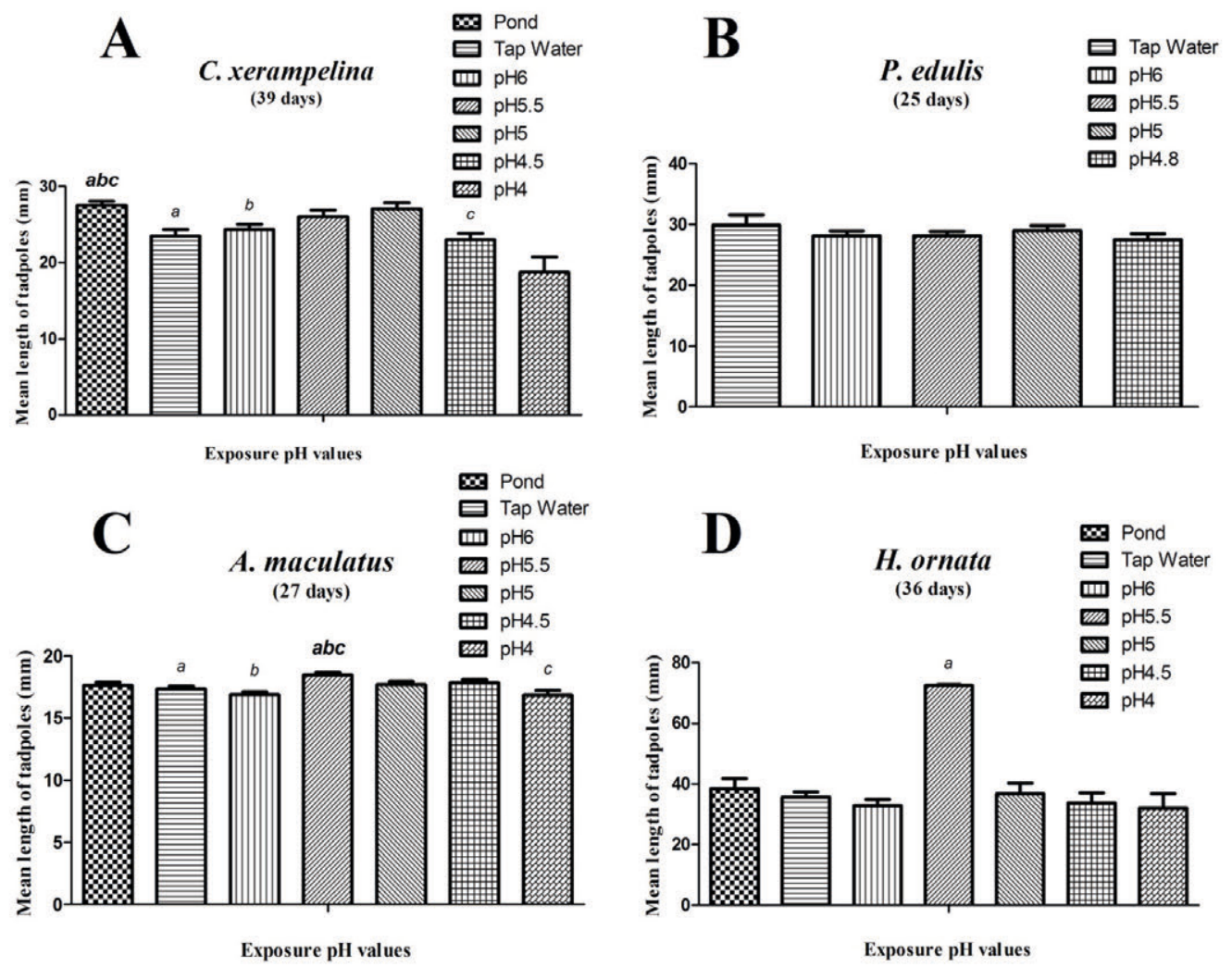

Figure 4

Mean and standard error of tadpole lengths ( $\mathrm{mm}$ ) for 4 frog species, up to the point that first metamorphoses were recorded (days in brackets), during the respective chronic exposure assays. Bars with common superscript indicate significantly different $p H$ exposures $(p<0.05)$.
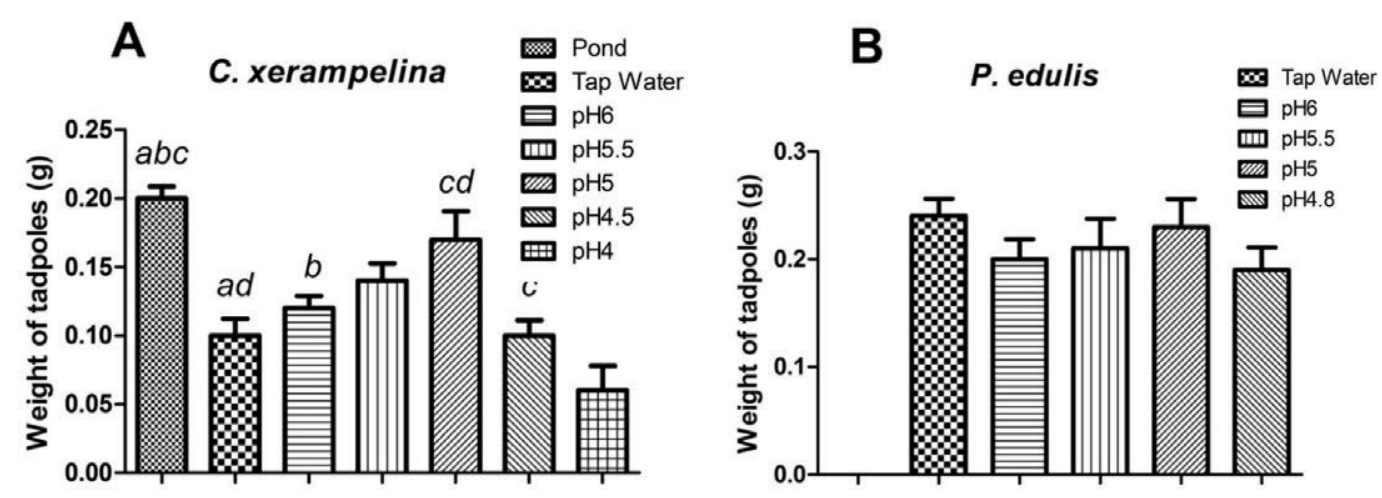

C

A. maculatus

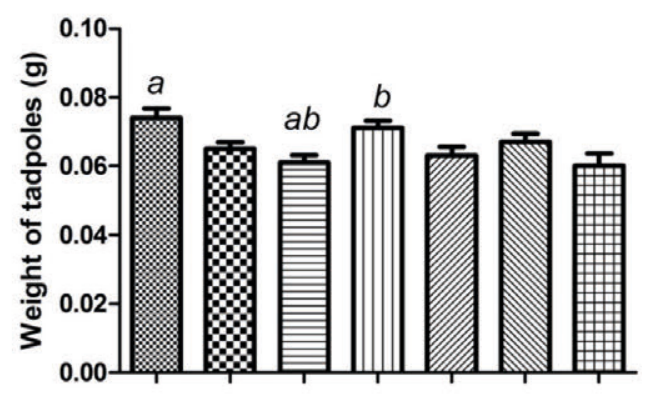

D. ornata

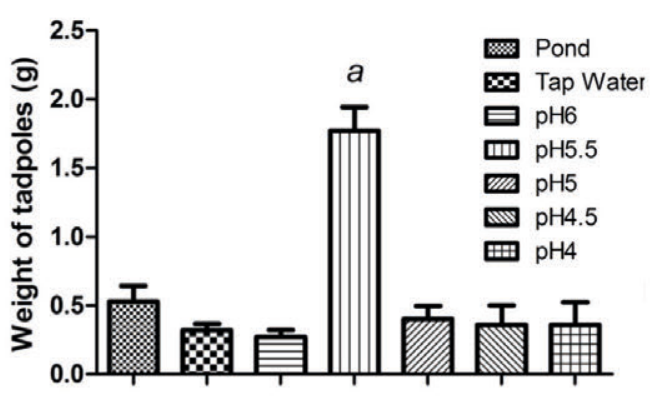

Figure 5

Mean and standard error of tadpole weights ( $g$ ) for 4 frog species at the end of their respective chronic exposure bioassays. Bars with common superscript indicate significantly different $p H$ exposures $(p<0.05)$ 
observations and not quantified for analysis in the present study. The toxic effects of acidity to amphibians vary depending on the developmental stage of the animal (Pierce, 1987). Amphibian larvae are generally more tolerant of acidity than embryos, and their acid tolerance increases as the larvae grow and develop (Pierce et al., 1984; Freda and Dunson, 1985). Adult frogs are the least sensitive to changes in acidity (Pierce, 1985).

For amphibian embryos, survival rate is usually high up to a threshold level of acidity (usually $\mathrm{pH}<4$ ), and then drops precipitously (Pierce, 1987). Our results concur, with the percentage of embryos hatching decreasing as the acidity of the solutions increased. For C. xerampelina and P. edulis none of the embryos that were exposed to $\mathrm{pH} 4$ and lower hatched, while for A. maculatus no embryos hatched at pH3.5. Numerous studies indicate that many amphibian embryos will stop cleaving at an early stage and development ceases when $\mathrm{pH}$ is below 4 (Pough and Wilson 1977; Pierce et al., 1984; Leuven et al., 1986). This could be one of the reasons for the embryos, exposed to the different $\mathrm{pH}$ solutions during this study, which did not develop fully. At the $\mathrm{pH}$ concentrations ranging from pH 4-5, the embryos will often develop completely, but some of the surrounding egg capsules will become opaque and eggs will appear shrunken. Under these conditions the 'curling defect' occurs (Gosner and Black, 1957; Pough 1976; Dunson and Connell, 1982; Pierce et al., 1984), where the embryo is curled tightly within the inner space of the capsules, and is unable to hatch successfully. This 'curling defect' can however be corrected by simply removing embryos from the egg capsules (Dunson and Connell, 1982). During the embryo exposures of this study, some of the embryos did become opaque and on average took a day longer to develop into tadpoles. As mentioned, the 'curling defect' could be a possible explanation for this phenomenon occurring during this assay.

A decrease in $\mathrm{pH}$ had toxic effects on tadpoles of all four frog species during the acute and chronic acid tolerance bioassays. The' $\mathrm{LC}_{50}$ ' values indicated that there is a difference in $\mathrm{pH}$-sensitivity among the different frog species. The Flatbacked Toad was the most tolerant to decreasing $\mathrm{pH}$, whereas the African Bullfrog is much more sensitive to changes in $\mathrm{pH}$. According to Pierce (1985) amphibians exhibit intraspecific variation in acid tolerance. Amphibians are not only negatively affected when $\mathrm{pH}$-levels are very low. Some species are also sensitive to slightly acidic conditions, and nonlethal effects such as decreased growth rates and increases in developmental abnormalities can occur at higher $\mathrm{pH}$. Pierce (1985) also states that amphibian acid tolerance is a multi-faceted phenomenon influenced by taxonomic, geographic, environmental, ecological and genetic factors. Thus the differences in acid tolerances of the four selected frog species can possibly be explained through the differences in their habitats or some genetic adaptations to acidic conditions. Pierce (1985) and Freda and Dunson (1984, 1985) state that interspecific variation in tadpole acid tolerance is related to their differences in body sodium content and sodium flux. Low sodium may be a possible adaptation for coping with increased acidic environmental conditions.

During the chronic exposures, the differences in acidity (different $\mathrm{pH}$ exposures) also proved to be toxic. It caused high tadpole mortality percentages in the sensitive species, the African Bullfrog. The other three species all had lower tadpole mortalities. Physical and behavioural abnormalities for chronic exposures, as noted through personal observation, were similar to that for the acute exposures. Low $\mathrm{pH}$ caused a decrease in tadpole growth rate, mobility and feeding, and also prolonged metamorphosis. This can possibly be explained by hydrogen ions interfering primarily with sodium flux in the tadpoles; low $\mathrm{pH}$ depresses sodium uptake and increases sodium loss (Freda and Dunson, 1984, 1985). Decreases in pH can not only cause all of the abovementioned negative effects in tadpoles and embryos, but also increase the possibility of developmental abnormalities occurring in adult frogs when metamorphosis is eventually completed.

For P. edulis, the length and weight of tadpoles in the $\mathrm{pH}$ 5.5 exposure were the highest. This may be explained by the lower density and therefore decreased competition for available food. Tadpoles of H. ornata are likely to resort to cannibalism, especially in captivity (Crump, 1990; Du Preez and Carruthers, 2009). This could explain the low numbers of tadpoles remaining in the $\mathrm{pH} 5.5$ solution, because larger tadpoles were seen feeding on others.

For most of the frog species, tadpoles from the control and higher $\mathrm{pH}$ exposures completed their metamorphosis cycles slightly before tadpoles from the low $\mathrm{pH}$ exposures. The number of days varied between the different species: for A. maculatus, the higher $\mathrm{pH}$ exposures finished between 1-2 weeks earlier than lower $\mathrm{pH}$ exposures, for $P$. edulis \pm 1 week earlier, for $H$. ornata \pm 4 weeks earlier and for C. xerampelina the higher $\mathrm{pH}$ exposures finished \pm 5 days earlier than lower $\mathrm{pH}$ exposures. It could thus be concluded that low $\mathrm{pH}$ might have delayed their natural metamorphosis. Tadpoles of P. edulis normally complete metamorphosis after 18-33 days (Du Preez and Carruthers, 2009). Tadpoles from pH 6 completed metamorphosis first, after 42 days, followed by tadpoles from $\mathrm{pH} 5$ and 4.8 after 43 days, while tadpoles from the tap water control and pH 5.5 only completed metamorphosis after 49 days. According to Du Preez and Carruthers (2009), the normal time for $A$. maculatus tadpoles to complete metamorphosis is 14 days. Exposed A. maculatus tadpoles started metamorphosis only after 36 days, more than double the documented number of days, and all tadpoles completed metamorphosis after 84 days (Table 3). Tadpoles from the tap water control were first to complete metamorphosis, after 52 days, followed by those exposed to $\mathrm{pH} 5.5$ and the pond water control, after 64 days. The last exposures to complete metamorphosis were $\mathrm{pH} 4.5$ and 4 , after 75 and 84 days, respectively. The normal metamorphosis cycles for Foam Nest Frogs and Ornate Frogs are not documented, but it took almost 5 months and 3 months, respectively, for these species' tadpoles to complete their metamorphosis. For $C$. xerampelina, as well as $H$. ornata tadpoles, the pond- and tap water controls completed metamorphosis before tadpoles from $\mathrm{pH}$ 4.5. The African Bullfrog tadpoles took 2 weeks longer than previously documented to complete their metamorphosis and the Flat-backed Toad tadpoles almost $2 \frac{1}{2}$ months longer.

The effects of low $\mathrm{pH}$ determined from this study might be subtle, but may have drastic and ecologically important consequences for many frog species, including the species assessed during this bioassay. Many amphibian species are significant components of many freshwater and terrestrial ecosystems and many breed in small, temporary ponds and pools (Pough, 1976) that dry up during the non-rainy season. Slower growth rates, caused by a decrease in $\mathrm{pH}$, may negatively affect these frog species. Firstly, tadpoles may fail to complete metamorphosis before the ponds or pools dry out, size at metamorphosis will be affected, the survival of frogs in the terrestrial environment will be influenced, and ultimately the reproductive success of these individuals will be compromised (Wilbur, 1972, 1976, 1977; Wilbur and Collins 1973; Berven and Gill 1983). Decreased growth rates as well as physical and behavioural abnormalities, caused by low $\mathrm{pH}$, will possibly also affect 
important processes and interactions that occur between frog species, such as predation and competition, which will ultimately impact their populations and possibly have ecological effects on other organisms that are part of their ecosystems.

During this project the average $\mathrm{pH}$ of natural ponds in the southern regions of the KNP was approximately 6.8 (Vlok et al., 2013). During the time period that the assays were conducted, the $\mathrm{pH}$ of rain water was 5.42 (Vlok et al., 2013). The ' $\mathrm{LC}_{50}{ }^{\prime} \mathrm{pH}-$ values calculated for the four frog species were all below 4 and therefore higher that measured in various ponds throughout the KNP (Vlok et al., 2013). The pH-levels measured in rainwater at certain times of the year in the southern and central KNP are only slightly higher than the $\mathrm{pH}$-tolerances ( $\mathrm{pH} 4 ; 4.5$ and 3.7) of these four species. Therefore, notwithstanding the low $\mathrm{pH}$ of rainwater, Vlok et al. (2013) attributed the neutral $\mathrm{pH}$ of the natural ponds to the natural buffering capacity of the anions in the sediments of these ponds. It is therefore unlikely that the acid precipitation in the KNP currently poses a risk to frog populations. However, of concern are the elevated sulphate levels that are recorded in the ponds once they start drying up (Vlok et al., 2013) and this may possibly have attributed to the mortalities that were observed in the pond water exposure groups during the field bioassays.

\section{CONCLUSIONS}

Based on the results from the present study and the literature (Blaustein and Johnson, 2003), it can be concluded that low $\mathrm{pH}$ influences amphibians in a variety of ways. The increases in acidity of frog breeding habitats causes a decrease in tadpole growth rates and increased developmental abnormalities of tadpoles as well as adult frogs, and can even cause direct mortalities. Toxic effects of low $\mathrm{pH}$ on amphibians are complex (Pierce, 1987), as are the responses of different amphibian species to acidic environments. The buffer capacity of the surface water in the study area is high due to the underlying geological structures (Vlok et al., 2013); thus it is unlikely that frog populations are currently at risk as a result of acid rain.

\section{ACKNOWLEDGEMENTS}

The authors wish to thank SANParks for logistic support and permission to work in KNP, and Dr Ruan Gerber and Dr Kyle McHugh for field assistance in collecting the frogs. Financial support for this project was provided by the Water Research Commission (WRC) of South Africa (Project K5-1928, Dr Wynand Vlok, PI). The authors wish to thank Dr Nancy Karraker for assistance in the experimental design. Opinions expressed and conclusions arrived at, are those of the authors and not that of the WRC.

\section{REFERENCES}

BERVEN KA and GILL DE (1983) Interpreting geographic variation in life-history traits. Am. Zool. 23 (1) 85-97. http://dx.doi.org/10.1093/ icb/23.1.85

BLAUSTEIN AR and JOHNSON PTJ (2003) The complexity of deformed amphibians. Front. Ecol. Environ. 1 (2) 87-94. http:// dx.doi.org/10.1890/1540-9295(2003)001[0087:TCODA]2.0.CO;2

BLAUSTEIN AR, WAKE DB and SOUSA WP (1994a) Amphibian declines: Judging stability, persistence, and susceptibility of populations to local and global extinctions. Conserv. Biol. 8 (1) 60-71. http://dx.doi.org/10.1046/j.1523-1739.1994.08010060.x

BLAUSTEIN AR, HOFFMAN PD, HOKIT DG, KIESECKER JM, WALLS SC and HAYS JB (1994b) UV repair and resistance to solar
UV-B in amphibian eggs: A link to population declines? (UV radiation/DNA repair). Proc. Natl. Acad. Sci. 91 1791-1795. http://dx.doi. org/10.1073/pnas.91.5.1791

BLAUSTEIN AR, ROMANSIC JM, KIESECKER JM and HATCH AC (2003) SPECIAL ISSUE: Amphibian declines: Ultraviolet radiation, toxic chemicals and amphibian population declines. Divers. Distrib. 9 123-140. http://dx.doi.org/10.1046/j.1472-4642.2003.00015.x

COLLETT KS, PIKETH SJ and ROSS KE (2010) An assessment of the atmospheric nitrogen budget on the South African Highveld. S. Afr. J. Sci. 106 (5/6), Art. \#220, 9 pages. http://dx.doi.org/10.4102/sajs. v106i5/6.220

COLLINS JP and STORFER A (2003) Global amphibian declines: sorting the hypotheses. Divers. Distrib. 9 89-98. http://dx.doi. org/10.1046/j.1472-4642.2003.00012.x

CRUMP ML (1990) Possible enhancement of growth in tadpoles through cannibalism. Copeia 1990 (2) 560-564. http://dx.doi. org/10.2307/1446361

DUNSON WA and CONNELL J (1982) Specific inhibition of hatching in amphibian embryos by low pH. J. Herpetol. 16 (3) 314-316. http:// dx.doi.org/10.2307/1563725

DU PREEZ L and CARRUTHERS V (2009) A Complete Guide to the Frogs of Southern Africa. Struik Nature, Cape Town. 146-147, 300-303, 410-417, 456-459.

EZEMONYE LIN and ENUNEKU A (2005) Evaluation of acute toxicity of cadmium and lead to amphibian tadpoles (Toad: Bufo maculatus and frog: Ptychadena bibroni). J. Aquat. Sci. 20 (1) 33-38. http://dx.doi.org/10.4314/jas.v20i1.20036

FREDA J and DUNSON WA (1984) Sodium balance of amphibian larvae exposed to low environmental pH. Physiol. Zool. 57 (4) 435-443.

FREDA J and DUNSON WA (1985) Field and laboratory studies of ion balance and growth rates of ranid tadpoles chronically exposed to Low pH. Copeia 2 415-423. http://dx.doi.org/10.2307/1444853

GOSNER KL (1960) A simplified table for staging anuran embryos and larvae with notes on identification. Herpetologica 16 183-190.

GOSNER KL and BLACK IH (1957) The effects of acidity on the development and hatching of New Jersey frogs. Ecology 38 (2) 256-262. http://dx.doi.org/10.2307/1931684

GRANT PK and LICHT LE (1993) Acid tolerance of anuran embryos and larvae from central Ontario. J. Herpetol. 27 (1) 1-6. http:// dx.doi.org/10.2307/1564897

HOPKINS WA, CONGDON J and RAY JK (2000) Incidence and impact of axial malformations in larval Bullfrogs (Rana catesbeiana) developing in sites polluted by a coal-burning power plant. Environ. Toxicol. Chem. 19 (4) 862-868. http://dx.doi. org/10.1897/1551-5028(2000)019<0862:IAIOAM >2.3.CO;2

HORNE MT and DUNSON WA (1995) Effects of low pH, metals, and water hardness on larval amphibians. Arch. Environ. Contam. Toxicol. 29 500-505.

HUANG H, WANG X, OU W, ZHAO J, SHAO Y and WANG L (2003) Acute toxicity of benzene derivatives to the tadpoles (Rana japonica) and QSAR analyses. Chemosphere 53 963-970. http://dx.doi. org/10.1016/S0045-6535(03)00715-X

JOSIPOVIC M, ANNEGARN HJ, KNEEN MA, PIENAAR JJ and PIKETH SJ (2010) Concentrations, distributions and critical level exceedance assessment of $\mathrm{SO}_{2}, \mathrm{NO}_{2}$ and $\mathrm{O}_{3}$ in South Africa. Environ. Monit. Assess. 171 (1) 181-196. http://dx.doi.org/10.1007/ s10661-009-1270-5

KIESECKER JM (2002) Synergism between trematode infection and pesticide exposure: A link to amphibian limb deformities in nature? Proc. Natl. Acad. Sci. 99 (15) 9900-9904. http://dx.doi. org/10.1073/pnas.152098899

LEUVEN RSEW, DEN HARTOG C, CHRISTIAANS MMC and HEIJLIGERS WHC (1986) Effects of water acidification on the distribution pattern and the reproductive success of amphibians. Experientia 42 495-503. http://dx.doi.org/10.1007/BF01946687

MARIAN MP, ARUL V and PANDIAN TJ (1983) Acute and chronic effects of carbaryl on survival, growth, and metamorphosis in the Bullfrog (Rana tigrina). Arch. Environ. Contam. Toxicol. 12 271-275. http://dx.doi.org/10.1007/BF01059402

MPHEPYA JN, PIENAAR JJ, GALY-LACAUX C, HELD G and 
TURNER CR (2004) Precipitation chemistry in semi-arid areas of Southern Africa: A case study of a rural and an industrial site. J. Atmos. Chem. 47 1-24. http://dx.doi.org/10.1023/ b:joch.0000012240.09119.c4

MPHEPYA JN, GALY-LACAUX C, LACAUX JP, HELD G and PIENAAR JJ (2006) Precipitation chemistry and wet deposition in Kruger National Park, South Africa. J. Atmos. Chem. 53 169-183.

OMONONA AO and EKPENKO V (2011) Haematology and prevalence of blood parasites of the common frog (Rana temporaria) in the tropical environment. J. Vet. Med. Anim. Health 3 (2) 14-20.

PIERCE BA (1985) Acid tolerance in amphibians. BioScience 35 (4) 239-243. http://dx.doi.org/10.2307/1310132

PIERCE BA (1987) The effects of acid rain on amphibians. The American Biology Teacher 49 (6) 342-347. http://dx.doi. org/10.2307/4448545

PIERCE BA, HOSKINS JB and EPSTEIN E (1984) Acid tolerance in Connecticut Wood Frogs (Rana sylvatica). J. Herpetol. 18 (2) 159-167. http://dx.doi.org/10.2307/1563744

POUGH FH (1976) Acid precipitation and embryonic mortality of spotted salamanders, Ambystoma maculatum. Sci. New Ser. 192 (4234) 68-70. http://dx.doi.org/10.1126/science.3852

POUGH FH and WILSON RE (1977) Acid precipitation and reproductive success of Ambystoma salamanders. Water Air Soil Pollut. 7 307-316. http://dx.doi.org/10.1007/BF00284127

SELVI M, GÜL A and YILMAZ M (2003) Investigation of acute toxicity of cadmium chloride $\left(\mathrm{CdCl}_{2} \mathrm{H}_{2} \mathrm{O}\right)$ metal salt and behavioural changes it causes on water frog (Rana ridibunda Pallas, 1771). Chemosphere 52 259-263. http://dx.doi.org/10.1016/ S0045-6535(03)00262-5

SPARLING DW, LINDER G, BISHOP CA and KREST S (2010) Ecotoxicology of Amphibians and Reptiles (2 ${ }^{\text {nd }}$ edn). SETAC Press, Pensacola, Florida. 103 pp.
VERTUCCI FA and CORN PS (1996) Evaluation of episodic acidification and amphibian declines in the Rocky Mountains. Ecol. Appl. 6 (2) 449-457. http://dx.doi.org/10.2307/2269382

VLOK W, FOUCHÉ PSO, COOK CL, WEPENER V and WAGENAAR GM (2013) An assessment of the current distribution, biodiversity and health of the frogs of the Kruger National Park in relation to physical and chemical factors. WRC Report No. 1928/1/12, Water Research Commission, Pretoria.

WILBUR HM (1972) Competition, predation, and the structure of the Ambystoma-Rana Sylvatica community. Ecology 53 (1) 3-21. http:// dx.doi.org/10.2307/1935707

WILBUR HM (1976) Density-dependent aspects of metamorphosis in Ambystoma and Rana Sylvatica. Ecology 57 (6) 1289-1296. http:// dx.doi.org/10.2307/1935053

WILBUR HM (1977) Interactions of food level and population density in Rana Sylvatica. Ecology 58 (1) 206-209. http://dx.doi. org/10.2307/1935124

WILBUR HM and COLLINS JP (1973) Ecological aspects of amphibian metamorphosis. Sci. New Ser. 182 (4119) 1305-1314.

WHILES MR, LIPS KR, PRINGLE CM, KILHAM SS, BIXBY RJ, BRENES R, CONNELLY S, CHECO COLON-GAUDI J, HUNTE-BROWN M, HURYN AD, MONTGOMERY C and PETERSON S (2006) The effects of amphibian population declines on the structure and function of Neotropical stream ecosystems. Front. Ecol. Environ. 4 (1) 27-34. http://dx.doi. org/10.1890/1540-9295(2006)004[0027:TEOAPD]2.0.CO;2

WHITFIELD SM, BELL KE, PHILIPPI T, SASA M, BOLANÕS F, CHAVES G, SAVAGE JM and DONNELLY MA (2007) Amphibian and reptile declines over 35 years at La Selva, Costa Rica. Proc. Natl. Acad. Sci. 104 (20) 8352-8356. http://dx.doi.org/10.1073/ pnas.0611256104 